\title{
The Due Process Clause and Students: The Road to a Single Approach of Determining Property Interests in Education
}

\section{Dalton Mott*}

\section{INTRODUCTION}

Imagine a university professor accuses a student of cheating on a final exam. Before the student can defend herself, the university decides to expel the student. Understandably, the student decides she wants to challenge the expulsion as a violation of her due process rights. Can the student challenge the action? Surprisingly, the answer depends on the federal circuit in which the student lives. In 1975, the United States Supreme Court held that state law could provide primary students a property interest in their education. ${ }^{1}$ However, forty years later, courts remain uncertain of when such an interest exists for university students.

In Goss v. Lopez, the Supreme Court extended due process protections to a group of high school students in Ohio. ${ }^{2}$ The Supreme Court determined that Ohio state law provided the high school students a property interest in their continued enrollment at the school and that the Due Process Clause protected such an interest. ${ }^{3}$ The Supreme Court did not address whether university students have a similar property interest. Since Goss, many university students have brought due process claims against their schools, but lower courts have struggled to determine when a university student's interest in education rises to the level of a property interest under the Due Process Clause. ${ }^{4}$

\footnotetext{
* J.D. Candidate, 2017, University of Kansas School of Law; B.A., 2014, University of TexasDallas. I would like to thank Ashley Akers and Professor Richard Levy for their edits and suggestions throughout the writing process for this Comment, M.J. Willoughby and Dennis Depew for inspiring and encouraging this topic, and the Kansas Law Review Board and Staff for all of their hard work and help in editing this Comment. Finally, I would like to thank my family and friends for all of their support in both writing this Comment and law school.

1. Goss v. Lopez, 419 U.S. 565, 574 (1975).

2. Id. at $577-79$.

3. Id. at $573-74$

4. See Barbara A. Lee, Judicial Review of Student Challenges to Academic Misconduct Sanctions, 39 J.C. \& U.L. 511, 524-25 (2013) (recognizing that circuits have reached different
} 
Lower courts adopt one of three approaches to determine whether a student has a property interest in education protected by the Due Process Clause. Under the first approach - the state-specific approach — courts analyze state law to determine whether it provides students a property interest. ${ }^{5}$ Under the second approach — the generalized approach-courts rely on Goss as a basis to provide all students a property interest in education regardless of state law. ${ }^{6}$ Under the final approach-the assumption approach-courts assume a property interest exists in education but do not decide the question. ${ }^{7}$

The lack of Supreme Court precedent on this issue has led to confusion and uncertainty for both lower courts and parties. ${ }^{8}$ Although students bring many due process claims each year, the question of whether a property interest exists remains unpredictable and varies by jurisdiction. ${ }^{9}$ For example, a student in the Tenth Circuit has a property interest in her education regardless of state law. ${ }^{10}$ In contrast, a student in the Fourth Circuit must prove state law provides her with a property interest, ${ }^{11}$ and a student in the Fifth Circuit is assumed to have a property interest in her education. ${ }^{12}$ Because of this uncertainty, courts may entertain meritless claims, which hurts both judicial efficiency and parties. $^{13}$

To address these concerns, federal courts should no longer avoid the property interest question; instead, courts should adopt the state-specific approach to determine whether a student has a property interest in her education. The Supreme Court has largely settled the property interest question for primary school students by finding that compulsory education laws create a property interest for all elementary and high school students. ${ }^{14}$ In contrast, the Supreme Court has not settled this question for higher education and thus this Comment focuses on undergraduate and graduate students. This Comment does not take a

\footnotetext{
results on whether students have a property interest in education).

5. See, e.g., Charleston v. Bd. of Trs. of the Univ. of Ill. at Chi., 741 F.3d 769, 772-74 (7th Cir. 2013).

6. See, e.g., Gorman v. Univ. of R.I., 837 F.2d 7, 12 (1st Cir. 1988).

7. See, e.g., Richmond v. Fowlkes, 228 F.3d 854, 857 (8th Cir. 2000).

8. See Fernand N. Dutile, Students and Due Process in Higher Education: Of Interests and Procedures, 2 FLA. COASTAL L.J. 243, 288-89 (2001).

9. See infra Sections II.B-C.

10. See infra Section II.B.2.

11. See infra Section II.B.1.

12. See infra Section II.C.2.

13. See infra Section III.A.2.

14. See infra Section III.B.2.b.
} 
position on whether students should or should not have a property interest in their education; instead, it focuses on why courts should adopt a single approach to education-based property interests.

This Comment's analysis is divided into two parts. The first part addresses why courts should no longer assume a student has a property interest in education. ${ }^{15}$ It will address why the assumption approach is not supported by Supreme Court precedent and will argue that it is time for courts to begin to decide the property interest question. The second part addresses why courts should use the state-specific approach instead of the generalized approach. ${ }^{16}$ This section will address why the generalized approach has undermined precedent on property interests and as a result has created a circuit split on whether the Constitution provides students a generalized property interest in their education. Finally, this section will address the advantages of the state-specific approach and explain how the approach is practical for courts to use.

\section{BACKGROUND}

Since Goss, education-based due process litigation has exploded in federal courts. ${ }^{17}$ One of the major issues in these cases is whether higher education students have a property interest in their education. ${ }^{18}$ The Supreme Court has heard two education due process claims since Goss, but in both cases the Supreme Court chose to assume, without deciding, that a property interest in education existed. ${ }^{19}$ Therefore, the Supreme Court did not reach the merits of the property interest issue. In the wake of the Supreme Court's reluctance to decide the issue, lower courts have struggled to determine whether students have a property interest in education, and unsurprisingly, circuits are split on the issue. ${ }^{20}$

This section proceeds in three parts. The first part discusses the background for Goss v. Lopez and property interests in general. The second part examines Goss and the two approaches that have arisen from the decision: the state-specific approach and the generalized approach.

\footnotetext{
15. See infra Section III.A.

16. See infra Section III.B.

17. See Deborah L. Ford \& John L. Strope, Jr., Judicial Responses to Adverse Academic Decisions Affecting Public Postsecondary Institution Students Since "Horowitz" and "Ewing”, 110 EDUC. L. REP. 517, 517 (1996) (analyizing fifty-nine education-based due process cases).

18. See infra Sections II.B-C.

19. See Bd. of Curators of the Univ. of Mo. v. Horowitz, 435 U.S. 78, 82-85 (1978); Regents of the Univ. of Mich. v. Ewing, 474 U.S. 214, 222-23 (1985).

20. See Dutile, supra note 8, at 254-58, 261-62.
} 
Finally, the third part examines the two later Supreme Court decisions, Board of Curators of the University of Missouri v. Horowitz and Regents of the University of Michigan v. Ewing, and the development of the assumption approach to property interests. ${ }^{21}$

\section{A. Due Process and Property Interests}

During the 1970s, the Supreme Court began a period known as the due process revolution, and Goss was a product of that revolution. ${ }^{22}$ Before the 1970s, the Supreme Court "routinely denied due process protection ... . [to] government service[s] [and] benefit[s]." 23 Courts viewed these benefits as privileges and not rights. ${ }^{24}$ During the due process revolution, the Supreme Court recognized many new property interests in government benefits. ${ }^{25}$ Many scholars have argued this change represented a radical shift in how the Supreme Court had always viewed property interests. ${ }^{26}$ Other scholars have criticized this position, though, instead arguing the Supreme Court was simply recognizing a long-term practice of protecting government benefits. ${ }^{27}$ While this Comment does not take a position on this debate, the debate does provide context for the Goss decision.

With this history in mind, there are two main questions that the Supreme Court uses to define property interests. The first question is what the source of property interests is. Property interests are a "positive law" concept, meaning they derive from another source of law. ${ }^{28}$ In Board of Regents of State Colleges v. Roth, the Supreme Court held that "[p]roperty interests, of course, are not created by the Constitution. Rather they are created and their dimensions are defined by existing rules or understandings that stem from an independent source such as state law." 29 Courts broadly define state law, and therefore, property interests can arise from a variety of sources such as statutes, regulations,

\footnotetext{
21. See Horowitz, 435 U.S. at 82-85; Ewing, 474 U.S. at 222-23.

22. Richard J. Pierce, Jr., The Due Process Counterrevolution of the 1990s?, 96 CoLUM. L. REV. 1973, 1973, 1983 (1996).

23. 1 Charles H. Koch, JR., AdMinistrative LaW AND Practice 71 (2d ed. 1997).

24. Id.

25. See Pierce, supra note 22, at 1973-80.

26. See, e.g., id. at 1980.

27. See, e.g., Sidney A. Shapiro \& Richard E. Levy, Government Benefits and the Rule of Law: Toward a Standards-Based Theory of Due Process, 57 ADMIN. L. REV. 107, 119-26 (2005).

28. Thomas W. Merrill, The Landscape of Constitutional Property, 86 VA. L. REV. 885, 920

21 (2000) (explaining the positive-law nature of property interests).

29. 408 U.S. 564, 577 (1972).
} 
contracts, or even implied contracts. ${ }^{30}$ Furthermore, implied contracts can come from many different sources such as handbooks or academic regulations. ${ }^{31}$ Aside from state law, other sources such as municipal law can also serve as a source for property interests. ${ }^{32}$

The second question is what qualifies as a property interest. Courts use a two-tiered system for determining what qualifies as a property interest. First, as previously mentioned, courts determine whether state law provides a valid entitlement, and second, courts determine whether the nature of the interest, rather than the weight or importance of the interest, deserves constitutional protection. ${ }^{33}$ The hallmark of a property interest is that the party "[has] a legitimate claim of entitlement to it." Merely having an adverse effect on a plaintiff when removed is not sufficient to create a property interest. ${ }^{35}$ Normally, a benefit does not qualify as a property interest if the state has discretion over the entitlement. ${ }^{36}$ Courts determine whether a state has discretion by looking to whether standards govern whether a benefit can be removed. ${ }^{37}$ Property interests go beyond traditional types of property, such as land or goods. ${ }^{38}$ They can include a wide range of government benefits. ${ }^{39}$ For example, the Supreme Court has recognized property interests in welfare benefits, ${ }^{40}$ government employment, ${ }^{41}$ social security benefits, ${ }^{42}$ and licenses. ${ }^{43}$ In summation, plaintiffs have protected property interests if they can show state law provides them a valid entitlement.

\footnotetext{
30. See Bishop v. Wood, 426 U.S. 341, 344-45 (1976).

31. See Ikpeazu v. Univ. of Neb., 775 F.2d 250, 253 (8th Cir. 1985) (citing Corso v. Creighton Univ., 731 F.2d 529, 531-33 (8th Cir. 1984)).

32. Bishop, 426 U.S. at 344-45.

33. See Rhonda Wasserman, Procedural Due Process: A Reference Guide to the UNITED STATES CONSTITUTION 31 (2004).

34. Roth, 408 U.S. at 577; see also Leis v. Flynt, 439 U.S. 438, 441-43 (1979).

35. See 2 Richard J. Pierce, JR., Administrative LaW TrEatise 579 (4th ed. 2002).

36. See Michael L. Wells \& Alice E. Snedeker, State-Created Property and Due Process of Law: Filling the Void Left by Engquist v. Oregon Department of Agriculture, 44 GA. L. REV. 161, 174 (2009) (describing the reasoning and conclusions of the Court in Town of Castle Rock v. Gonzales, 545 U.S. 748, 756 (2005)).

37. See KocH, supra note 23 , at 78.

38. Wells \& Snedeker, supra note 36 , at 172.

39. Id.

40. Goldberg v. Kelly, 397 U.S. 254, 262-63 (1970).

41. Cleveland Bd. of Educ. v. Loudermill, 470 U.S. 532, 539 (1985).

42. Mathews v. Eldridge, 424 U.S. 319, 332 (1976).

43. Bell v. Burson, 402 U.S. 535, 539 (1971).
} 


\section{B. Goss v. Lopez}

Goss serves as the main framework for education-based due process claims. In Goss, a high school suspended a group of students for ten days for disciplinary reasons. ${ }^{44}$ The students brought a due process claim against the school, alleging that they were not provided sufficient process. $^{45}$ The district court-made up of a three-judge paneldetermined that the students had a protected interest in their education and that the school had denied them required process. ${ }^{46}$ The defendants appealed the decision, and pursuant to statute, the Supreme Court directly heard the case. ${ }^{47}$ The first issue the Supreme Court decided was whether the students had a property interest in their continued enrollment at the school. ${ }^{48}$ The Supreme Court first noted that Board of Regents $v$. Roth requires property interests to derive from an independent source of law. ${ }^{49}$ Then, the Supreme Court held that "on the basis of state law, [the students] plainly had legitimate claims of entitlement to a public education." 50 The Supreme Court found that the property interests derived from two Ohio state laws: the first provided free education to all residents between the ages of five and twenty-one and the second made education compulsory for students. ${ }^{51}$ After determining there was a property interest, the Supreme Court next determined that the property deprivation was "not de minimis," or not trivial, and thus should receive protection under the Due Process Clause. ${ }^{52}$ The Supreme Court went on to decide that the school did not provide the students sufficient process and that the school should have provided the students a hearing and notice of what they were accused of. ${ }^{53}$

Since Goss, many students have brought due process claims against educational institutions. ${ }^{54}$ Over time, courts have extended Goss in a variety of ways. For example, some courts have extended Goss from

\footnotetext{
44. Goss v. Lopez, 419 U.S. 565, 568 (1975).

45. Id. at $568-69$.

46. Lopez v. Williams, 372 F. Supp. 1279, 1300, 1302 (S.D. Ohio 1973), aff'd sub nom. Goss v. Lopez, 419 U.S. 565 (1975).

47. Goss, 419 U.S. at 572 (noting jurisdiction pursuant to 28 U.S.C. § 1253 (2012)).

48. Id. at $572-74$.

49. Id. at 572-73 (citing Bd. of Regents of State Colls. v. Roth, 408 U.S. 564, 577 (1972)).

50. Id. at 573 .

51. Id. at 573-74 (citing OHio Rev. CodE ANN. §§ 3313.48, 3313.64, 3321.04 (West 1972 \& Supp. 1973)).

52. Id. at 576 .

53. Id. at $580-84$

54. Ford \& Strope, supra note 17 (discussing fifty-nine education-based due process cases).
} 
primary students to undergraduate students. ${ }^{55}$ Some courts have also extended due process protections to graduate and professional students. ${ }^{56}$ The Supreme Court has not yet addressed whether a college or graduate student has a property interest in her education. ${ }^{57}$

The question of whether a student has a property interest in her education has become a major source of dispute in lower courts. ${ }^{58}$ Goss has caused a circuit split on how to determine whether a student has a property interest in higher education. ${ }^{59}$ Courts have used three main approaches when making this determination. The first approach is to look at each specific state's education laws to determine whether they provide a property interest. ${ }^{60}$ The second approach is to not consider state law and instead find a generalized property interest in education. ${ }^{61}$ The third approach-where courts assume a property interest in education exists - is discussed in Section II.C of this Comment. While courts may have a primary method to determine property interests in education, courts may use different approaches, even within the same circuit. $^{62}$

55. Dina Lallo, Note, Student Challenges to Grades and Academic Dismissals: Are They Losing Battles?, 18 J.C. \& U.L. 577, 579 (1992).

56. See, e.g., Borrell v. Bloomsburg Univ., 955 F. Supp. 2d 390, 402-03 (M.D. Pa. 2013).

57. See Hennessy v. City of Melrose, 194 F.3d 237, 249 (1st Cir. 1999); Doe v. Alger, 175 F. Supp. 3d 646, 656 (W.D. Va. 2016).

58. See, e.g., Hennessy, 194 F.3d at 249-50; Branum v. Clark, 927 F.2d 698, 705 (2d Cir. 1991); Davis v. George Mason Univ., 395 F. Supp. 2d 331, 335-36 (E.D. Va. 2005), aff'd, 193 F. App'x 248 (4th Cir. 2006); Charleston v. Bd. of Trs. of the Univ. of Ill. at Chi., 741 F.3d 769, 77274 (7th Cir. 2013).

59. See Jenkins v. Hutton, 967 F. Supp. 277, 282 (S.D. Ohio 1997).

60. See infra Section II.B.1.

61. See infra Section II.B.2.

62. Compare Gaspar v. Bruton, 513 F.2d 843, 850 (10th Cir. 1975) (using the generalized approach), with Trotter v. Regents of the Univ. of N.M., 219 F.3d 1179, 1184 (10th Cir. 2000) (using the state-specific approach). 


\section{The State-Specific Approach to Education Property Interests}

The state-specific approach requires both plaintiffs and courts to carefully examine state law to determine whether a student has a property interest in her education. Currently the Second, ${ }^{63}$ Third, ${ }^{64}$ Fourth, ${ }^{65}$ Seventh, ${ }^{66}$ Ninth, ${ }^{67}$ and Eleventh ${ }^{68}$ Circuits utilize a statespecific approach. Courts that use a state-specific approach reject the notion that Goss recognizes a generalized property interest in education. ${ }^{69}$ Instead, these courts interpret Supreme Court precedent such as Board of Regents of State Colleges $v$. Roth to require a student to show she has a property interest based on a legitimate entitlement from state law. ${ }^{70}$ For example, students could show that a state statute directly provides a property interest in her continued enrollment. ${ }^{71}$ A student could also show that under state law the relationship between a student and an educational institution is contractual in nature, and thus a property interest can arise from that relationship. ${ }^{72}$ For example, a student could show that the university's academic rules and regulations guaranteed that the university could not remove students without providing process. ${ }^{73}$ Therefore, in these circuits, a student bringing a due process claim must first allege a property interest that is specific to state law and that provides a legitimate claim of entitlement.

63. See, e.g., Branum v. Clark, 927 F.2d 698, 705 (2d Cir. 1991); Ezekwo v. N.Y.C. Health \& Hosps. Corp., 940 F.2d 775, 782-83 (2d Cir. 1991).

64. See, e.g., Borrell v. Bloomsburg Univ., 955 F. Supp. 2d 390, $402-03$ (M.D. Pa. 2013); Ross v. Pa. State Univ., 445 F. Supp. 147, 152-53 (M.D. Pa. 1978).

65. See, e.g., Davis v. George Mason Univ., 395 F. Supp. 2d 331, 335-36 (E.D. Va. 2005), aff'd, 193 F. App'x 248 (4th Cir. 2006).

66. See, e.g., Charleston v. Bd. of Trs. of the Univ. of Ill. at Chi., 741 F.3d 769, 772-74 (7th Cir. 2013).

67. See, e.g., Wynar v. Douglas Cty. Sch. Dist., 728 F.3d 1062, 1072 (9th Cir. 2013); T.T. v. Bellevue Sch. Dist., 376 F. App'x 769, 770-71 (9th Cir. 2010).

68. See, e.g., Barnes v. Zaccari, 669 F.3d 1295, 1303-05 (11th Cir. 2012).

69. See, e.g., Charleston, 741 F.3d at 772 (first citing Bissessur v. Ind. Univ. Bd. of Trs., 581 F.3d 599, 601 (7th Cir. 2009); and then citing Williams v. Wendler, 530 F.3d 584, 589 (7th Cir. 2008)) (finding that no "stand-alone property interest" exists for university students in their continued enrollment).

70. See, e.g., Barnes, 669 F.3d at 1303-05 (citing Bd. of Regents of State Colls. v. Roth, 408 U.S. 564, $577(1972))$.

71. See, e.g., Harris v. Blake, 798 F.2d 419, 422 (10th Cir. 1986) (holding a Colorado statute provides a direct entitlement to public education).

72. See, e.g., Charleston, 741 F.3d at 772-74 (citing Bissessur, 581 U.S. at 601) (finding that state law could provide that a student-university relationship is contractual in nature).

73. See, e.g., Ikpeazu v. Univ. of Neb., 775 F.2d 250, 253 (8th Cir. 1985). 
To illustrate how this approach works in practice, Leone v. Whitford, from the District of Connecticut, provides a good example. ${ }^{74}$ Leone brought a due process claim alleging that Central Connecticut State University did not provide her sufficient process when the University decided not to grant her a teaching degree. ${ }^{75}$ Leone only cited an implied contract as the source of her property interest and did not allege any other sources. ${ }^{76}$ The district court first noted that property interests must arise from independent sources of law such as state law. ${ }^{77}$ The district court also noted that contracts, expressed or implied, can serve as a basis for a property interest. ${ }^{78}$ The district court then discussed whether Leone had an implied contract with the school based upon promises made to her by university officials. ${ }^{79}$ The district court determined there was not an implied contract because the University retained the power to modify the agreement (i.e., expel her from the University) at any time. ${ }^{80}$ Therefore, the district court concluded that there was not an alleged property interest because there was no contract, and thus the court dismissed her claim. ${ }^{81}$

\section{The Generalized Approach to Education Property Interests}

The second approach to determine whether a property interest exists in education is the generalized approach, where courts recognize a generalized property interest in education. Currently, the First, ${ }^{82}$ Sixth ${ }^{83}$ and Tenth $^{84}$ Circuits utilize the generalized approach. These circuits have extended property interests in primary education to higher education without considering state law. ${ }^{85}$ Courts using the generalized

\footnotetext{
74. No. 3-05-cv-823 (JCH), 2007 WL 1191347 (D. Conn. Apr. 19, 2007), aff'd, 300 F. App'x 99 (2d Cir. 2008).

75. Id. at $* 1$.

76. Id. at $* 6$.

77. Id. at *8 (citing Ezekwo v. N.Y.C. Health \& Hosps. Corp., 940 F.2d 775, 782 (2d Cir. 1991)).

78. Id. (first citing Ezekwo, 940 F.2d at 782; and then citing Perry v. Sindermann, 408 U.S. $593,602(1972))$.

79. Id. at *8-9 ("More importantly, it is also apparent that CCSU and Whitford retained the authority to override whatever agreements the School's subordinate officers were making with Leone.").

80. Id. at $* 8-9$.

81. Id. at $* 9-10$.

82. See, e.g., Gorman v. Univ. of R.I., 837 F.2d 7, 12 (1st Cir. 1988).

83. See, e.g., Martinson v. Regents of the Univ. of Mich., 562 F. App'x 365, 372 (6th Cir. 2014); Flaim v. Med. Coll. of Ohio, 418 F.3d 629, 633-34 (6th Cir. 2005).

84. See, e.g., Gaspar v. Bruton, 513 F.2d 843, 850 (10th Cir. 1975); Gossett v. Okla. ex rel. Bd. of Regents for Langston Univ., 245 F.3d 1172, 1181 (10th Cir. 2001).

85. See infra Section III.B.
} 
approach interpret Supreme Court precedent, such as Goss v. Lopez, as requiring courts to find that students have a property interest in their education. ${ }^{86}$ For example, in Gorman v. University of Rhode Island, the First Circuit held that "[i]t is . . not questioned that a student's interest in pursuing an education is included within the fourteenth amendment's protection of liberty and property." ${ }^{\circ 7}$ After determining Goss provided a generalized property interest, the Gorman court decided that process was sufficient. ${ }^{88}$ Courts using this approach do not typically analyze state law; instead courts rely on precedent within their circuit to find a property interest exists. ${ }^{89}$

Lee v. Kansas State University, from the District of Kansas, exemplifies how this approach works in practice. ${ }^{90}$ In Lee, the plaintiff brought a due process claim alleging that Kansas State University violated her procedural due process rights when the University dismissed her from a graduate studies program. ${ }^{91}$ The district court first noted that Goss held that "once provided, public education becomes 'a property interest which may be protected by the Due Process Clause." "92 Relying on Tenth Circuit precedent, the district court acknowledged that the Tenth Circuit has "extended and expanded this right," such that there is now "a more generalized property interest in continuing graduate education." 93 Therefore, the district court concluded, "the Tenth Circuit recognizes a constitutional right to due process before a student can be deprived of her property interest in her continued enrollment and graduate education." 94 Notably, the district court did not reference or consider state law in its determinations; instead, the district court made clear that Goss and Tenth Circuit precedent provided the plaintiff a generalized property interest. ${ }^{95}$

\footnotetext{
86. See, e.g., Gorman, 837 F.2d at 12 (citing Goss v. Lopez, 419 U.S. 565, 574-75 (1975), as a basis for a student's property interest in education).

87. Id. (emphasis added) (citing Goss, 419 U.S. at 574-75).

88. Id. at $12-16$.

89. See, e.g., Gossett, 245 F.3d at 1181 (citing Harris v. Blake, 798 F.2d 419, 422 (10th Cir. 1986)).

90. No. 12-cv-2638-JAR-DJW, 2013 WL 2476702 (D. Kan. June 7, 2013).

91. Id. at *4.

92. Id. at *6 (quoting Goss, 419 U.S. at 574).

93. Id. (quoting Gaspar v. Bruton, 513 F.2d 843, 850 (10th Cir. 1975)).

94. Id.

95. See id.
} 


\section{Liberty Interests}

In addition to property interests, students may also have a liberty interest in their education. This Comment does not directly address whether a liberty interest exists, but such an interest may represent an alternative source of protection for students. "The Supreme Court has declined to define liberty with 'any great precision," but the Supreme Court has defined the concept broadly. ${ }^{96}$ For example, a person may have a protected liberty interest when the government puts that person's reputation at risk. ${ }^{97}$ In Goss, the Supreme Court held that academicrelated actions "could seriously damage the students' standing with their fellow pupils and their teachers as well as interfere with later opportunities for higher education and employment." 98 Therefore, the Supreme Court held that students in primary school have a liberty interest in their education. ${ }^{99}$

After Goss, a major question was whether liberty interests also applied to students in higher education, a question that has not yet been settled. ${ }^{100}$ For example, when the Supreme Court had the opportunity to address the issue, it chose to assume a liberty interest existed without deciding the issue. ${ }^{101}$ Lower courts have commonly used this approach when addressing liberty interests. ${ }^{102}$ Courts that have reached the merits of the issue have reached different results with some finding that a liberty interest exists, while other courts have found that no such interest exists. ${ }^{103}$ While the liberty interest issue is unsettled, it does represent a possible way for students to access due process outside of property interests.

\footnotetext{
96. WASSERMAN, supra note 33, at 41 (quoting Bolling v. Sharpe, 347 U.S. 497, 499 (1954)).

97. Goss v. Lopez, 419 U.S. 565, 574 (1975) (first quoting Wisconsin v. Constantineau, 400 U.S. 433, 437 (1971); and then citing Bd. of Regents of State Colls. v. Roth, 408 U.S. 564, 573 (1972)).

98. Id. at 575

99. Id. at $575-76$

100. See Lallo, supra note 55, at 579-81.

101. See Bd. of Curators of the Univ. of Mo. v. Horowitz, 435 U.S. 78, 84-85 (1978).

102. See, e.g., Smith v. Davis, 507 F. App'x 359, 362-63 (5th Cir. 2013).

103. Compare Jaksa v. Regents of the Univ. of Mich., 597 F. Supp. 1245, 1247-48 (E.D. Mich. 1984) (first citing Goss, 419 U.S. at 575; then citing Wisconsin v. Constantineau, 400 U.S. 433, 437 (1971); and then citing Bd. of Regents of State Colls. v. Roth, 408 U.S. 564 (1972)) (finding that a liberty interest existed), aff'd, 787 F.2d 590 (6th Cir. 1986), with Shaboon v. Duncan, 252 F.3d 722, 729-32 (5th Cir. 2001) (holding that the plaintiff did not have a liberty interest).
} 


\section{Horowitz and Ewing}

After Goss, the Supreme Court has twice heard education-based due process claims at the university level but in both cases chose to forgo the property interest question. ${ }^{104}$ These cases serve as the basis for a third approach for addressing property interests in education. This approach avoids the property interest question altogether by assuming a property interest exists. In both Horowitz and Ewing, the Supreme Court assumed that a property interest existed in education without deciding the question and then went on to determine that the student received the required amount of process under the law. ${ }^{105}$ Since Horowitz and Ewing, it has become common for lower courts to use the assumption approach when addressing student due process claims. ${ }^{106}$

\section{The Supreme Court Revisits the Education Due Process Question}

The assumption approach is the result of two Supreme Court cases, Horowitz and Ewing. In Horowitz, a medical student brought a due process claim against the University of Missouri-Kansas City for dismissing her for academic reasons. ${ }^{107}$ The Supreme Court first discussed whether Horowitz had a protected interest. ${ }^{108}$ The Supreme Court noted that the plaintiff never alleged a property interest, but that if she were to do so, she would have to rely upon Missouri state law to have a valid claim. ${ }^{109}$ Nevertheless, the Supreme Court assumed the plaintiff had a property interest in her case without deciding the question. ${ }^{110}$ Instead of addressing the property interest question, the Supreme Court found that the University provided the plaintiff sufficient process under the Fourteenth Amendment, and therefore the Supreme Court never determined whether the student had a property interest in her education. ${ }^{111}$

\footnotetext{
104. See Horowitz, 435 U.S. at 84-85; Regents of the Univ. of Mich. v. Ewing, 474 U.S. 214, 222-23 (1985).

105. Horowitz, 435 U.S. at 84-85; Ewing, 474 U.S. at 222-23.

106. Joseph M. Flanders, Academic Student Dismissals at Public Institutions of Higher Education: When Is Academic Deference Not an Issue?, 34 J.C. \& U.L. 21, 22 (2007).

107. Horowitz, 435 U.S. at $79-80$.

108. Id. at 82 .

109. Id.

110. Id. at $84-85$.

111. Id.
} 
Seven years later, the Supreme Court, in Ewing, revisited the question of whether a university student has a property interest in his education. ${ }^{112}$ In Ewing, the University of Michigan dismissed a student for failing an examination. ${ }^{113}$ As a result, the student brought a substantive due process challenge against the University for violating his due process rights. ${ }^{114}$ Ewing alleged that he had a property interest in his continued enrollment in his academic program. ${ }^{115}$ The Supreme Court, relying on Horowitz, assumed the plaintiff had a property interest without deciding the question and instead looked to whether process was sufficient. ${ }^{116}$ The Supreme Court relied upon the principle of constitutional avoidance to justify its decision. ${ }^{117}$ Notably, the University of Michigan asked the Supreme Court to assume a property interest existed instead of disputing whether such an interest existed. ${ }^{118}$ There are two main takeaways from these cases. First, the Supreme Court did not address the merits of whether a student has a property interest in her education because the Court only assumed such an interest existed without deciding the question. ${ }^{119}$ Second, these cases have served as the basis for the assumption approach to property interests in education. ${ }^{120}$

\section{The Assumption Approach in Action}

While the Supreme Court's assumption approach did not create precedent on the issue of whether a property interest existed, courts commonly use this approach when addressing student due process claims. ${ }^{121}$ Currently the Fifth $^{122}$ and Eighth ${ }^{123}$ Circuits almost exclusively use the assumption approach when addressing property interests in student due process cases. The assumption approach is

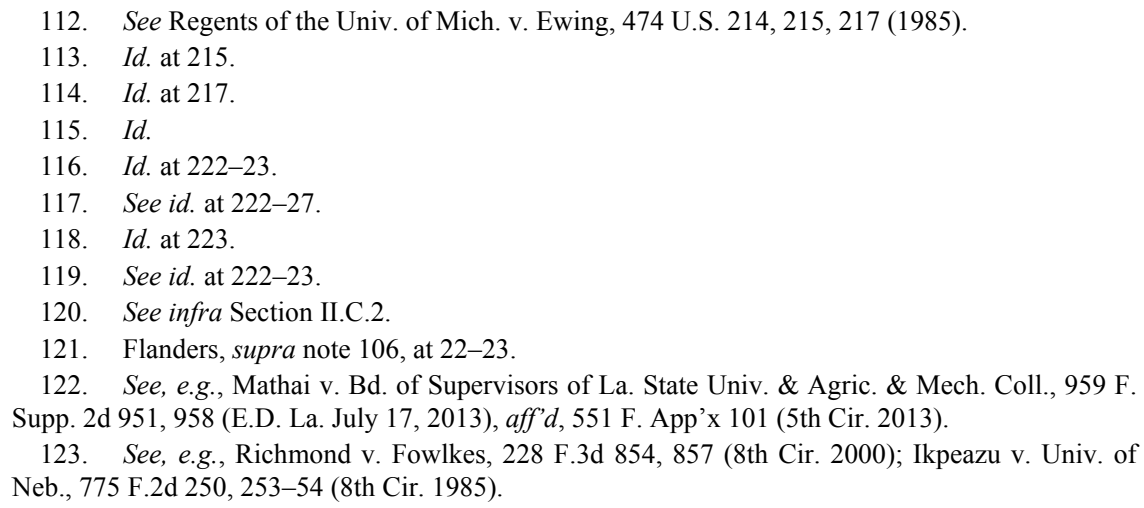


different from other approaches this Comment has addressed because it does not actually decide whether a student has a property interest. ${ }^{124}$ Instead, the assumption approach serves as a gap-filler for courts to avoid the property interest question, unless the particular facts of a case require that it does so. Instead of deciding whether a property interest exists, many courts proceed straight to determining whether a university provided a student sufficient process. ${ }^{125}$

To illustrate how this approach works in practice, Mathai v. Board of Supervisors of Louisiana State University and Agricultural and Mechanical College, from the Eastern District of Louisiana, provides a helpful example of the assumption approach. ${ }^{126}$ In Mathai, the plaintiff brought a due process claim against the University for her dismissal from the University. ${ }^{127}$ The district court first stated that for a plaintiff to have a valid due process claim she must show a deprivation of a property interest and that the University deprived her of constitutionally required procedure. ${ }^{128}$ The district court then noted the defendant did not dispute that the plaintiff had a property interest in her education. ${ }^{129}$ Nevertheless, the district court "assume[d] without deciding that plaintiff has a property ... interest in her continuing education at LSU."130 The district court recognized two reasons for doing so. ${ }^{131}$ The first was that neither the Supreme Court nor the Fifth Circuit has recognized that such an interest existed. ${ }^{132}$ The second was that the district court determined that the plaintiff received sufficient process, and therefore her claim could not succeed whether she had a property interest or not. ${ }^{133}$ In summation, courts have developed three different approaches to determine whether students have property interests in their education, and these three approaches represent a circuit split that should be resolved.

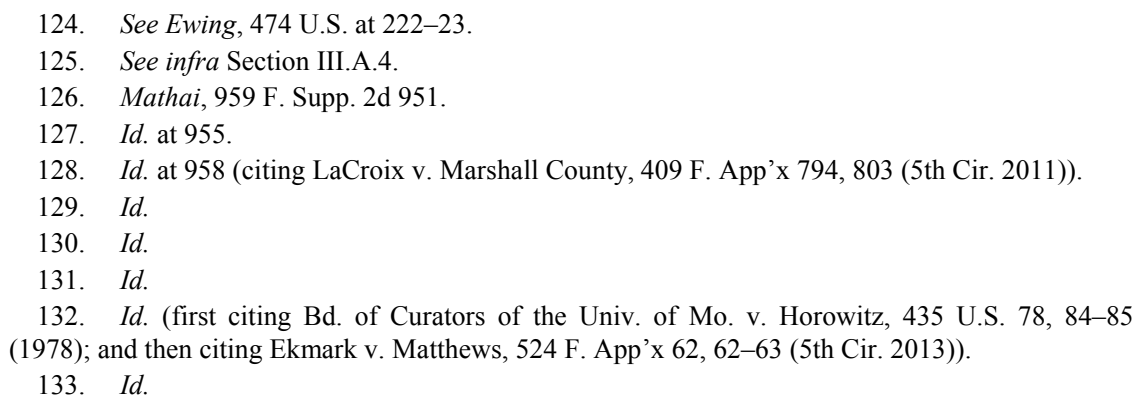




\section{ANALYSIS}

When courts address due process claims brought by students, they should decide whether a student has a property interest in her education, instead of avoiding the question, and courts should use a state-specific approach for determining whether such a property interest exists. Federal circuits currently use either a state-specific approach, a generalized approach, or an assumption approach to address whether a student has a property interest in her education. ${ }^{134}$ These conflicting approaches create a circuit split that causes confusion for lower courts, students, and higher education institutions. ${ }^{135}$ Courts should resolve this circuit split by adopting a single approach — the state-specific approachwhen dealing with education-based property interests.

This section proceeds in two parts. The first part addresses why courts should stop avoiding the property interest question. ${ }^{136}$ Instead, courts should decide these questions if given the opportunity. Courts should do so because the property interest question is a preliminary question in a due process claim and cannot be avoided under the principle of constitutional avoidance. Additionally, courts should decide the property interest question because it will provide needed guidance to lower courts and parties.

The second part addresses why courts should use the state-specific approach to property interests, instead of the generalized approach. ${ }^{137}$ When courts consider whether a student in higher education has a property interest in her education, they should look to state law to determine whether such an interest exists. Courts should do so because the state-specific approach most closely follows Supreme Court precedent and avoids conflicts between circuits. Furthermore, the statespecific approach is practical to use and is unlikely to reduce protections for students in higher education.

\footnotetext{
134. See supra Sections II.B-C.

135. See infra Sections III.A, III.B.1.c.

136. See infra Section III.A.

137. See infra Section III.B.
} 


\section{A. Courts Should Decide Whether Students Have a Property Interest in Their Education, Instead of Assuming Such an Interest Exists}

Thirty years have passed since the Supreme Court decided Horowitz and Ewing, but for many students it remains unclear whether they have a property interest in their education. Over the past three decades, federal courts have frequently used the assumption approach for property interests in education. ${ }^{138}$ This approach has hurt judicial efficiency and parties by creating uncertainty about whether such claims are valid. ${ }^{139}$ It is time for courts to stop avoiding this question and instead decide whether higher education students have a property interest in their education.

\section{Constitutional Avoidance}

In both Horowitz and Ewing, the Supreme Court relied upon the principle of constitutional avoidance as the justification for assuming that a property interest existed, ${ }^{140}$ but this is not an appropriate use of the constitutional avoidance principle. Constitutional avoidance is a principle that requires a court to avoid deciding constitutional issues if it can decide the case on other grounds, such as an issue of state law. ${ }^{141}$ The principle requires courts to consider whether a constitutional issue is "absolutely necessary to a decision of the case." "142 The Supreme Court normally uses the principle when it can rely on other grounds such as a statutory question to decide the outcome of a case. ${ }^{143}$ The purpose of the principle is to ensure that the Supreme Court does not issue advisory opinions on questions that state law can adequately address. ${ }^{144}$ The Supreme Court has not consistently applied the principle because of the difficultly of determining "which constitutional determinations are necessary."145 Nevertheless, the Supreme Court has made it clear that

\footnotetext{
138. See, e.g., Smith v. Davis, 507 F. App'x 359, 362-63 (5th Cir. 2013) (recognizing the large amount of use of the assumption approach).

139. See infra Sections III.A.2-4.

140. See Bd. of Curators of the Univ. of Mo. v. Horowitz, 435 U.S. 78, 84-85 (1978); Regents of the Univ. of Mich. v. Ewing, 474 U.S. 214, 222-23 (1985).

141. Ashwander v. Tenn. Valley Auth., 297 U.S. 288, 346-47 (1936) (Brandeis, J., concurring).

142. Id. at 347 (quoting Burton v. United States, 196 U.S. 283, 295 (1905)).

143. See Charles Gardner Geyh, The Dimensions of Judicial Impartiality, 65 FLA. L. REV. 493, 517 (2013).

144. Herb v. Pitcairn, 324 U.S. 117, 126 (1945) ("[I]f the same judgment would be rendered by the state court after we corrected its views of federal laws, our review could amount to nothing more than an advisory opinion.").

145. See Lisa A. Kloppenberg, Avoiding Constitutional Questions, 35 B.C. L. REV. 1003, 1028
} 
the application of the rule must largely be done on a case-by-case basis. $^{146}$

The determination of property interests, though, is not the type of issue that constitutional avoidance is meant to avoid, because they are a fundamental part of any due process question. ${ }^{147}$ In a due process challenge, a plaintiff must show she faced a deprivation of a property interest, and therefore a plaintiff's claim is only valid if she has such an interest. ${ }^{148}$ Courts have consistently held that the question of whether there is a property interest should come first in a due process case. ${ }^{149}$ "The Court has rendered numerous decisions in the wake of Roth reaffirming the idea that property is a precondition of procedural due process protection." 150 This is a logical approach because due process requires the courts to consider what level of process is sufficient and that level changes depending on the property interest. ${ }^{151}$ Thus, if the property interest is not defined, it is unclear which level of process the Constitution would require. ${ }^{152}$ Furthermore, courts routinely dismiss due process cases when the plaintiff does not present a valid property interest. ${ }^{153}$ Courts should not use constitutional avoidance in this context because due process claims require that the plaintiff have a protected interest, and thus that question is "absolutely necessary to a decision of the case." 154

A second major issue with constitutional avoidance-in this context - is that the property interest question is a construction of state law, not a constitutional question. ${ }^{155}$ The Supreme Court has made it clear that independent sources of law-not the Constitution-create property interests. ${ }^{156}$ Therefore, when a court decides whether a property

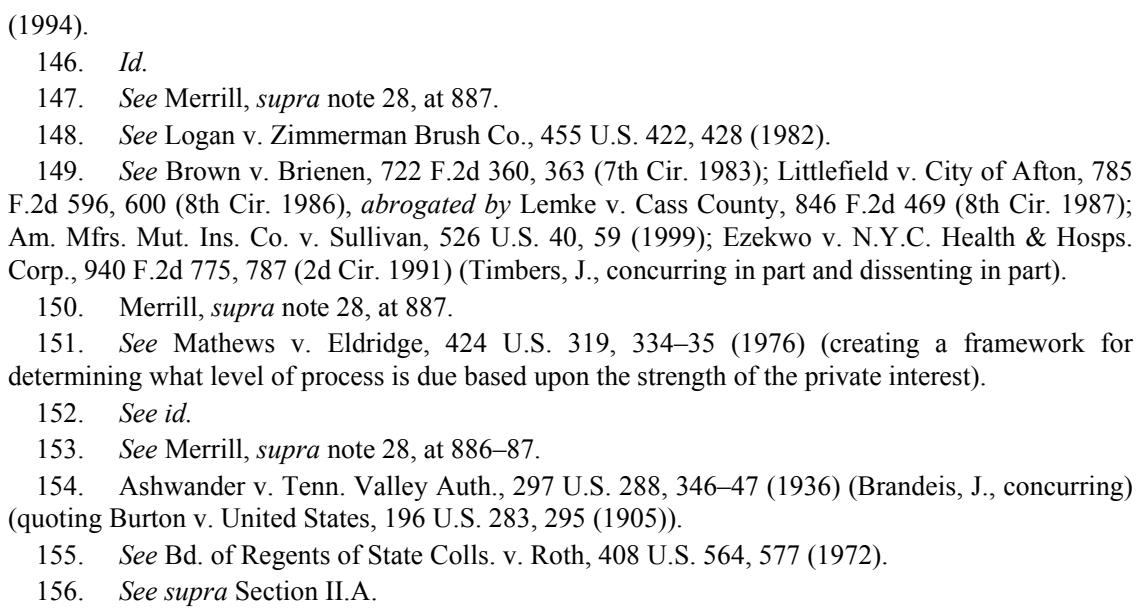


interest exists, it looks to construct state law and not to make constitutional determinations. ${ }^{157}$ In contrast, the issue of whether a defendant provided a plaintiff sufficient process is a constitutional question. ${ }^{158}$ Courts must consider whether a defendant provided the plaintiff "constitutionally adequate procedures" to protect her property interest. ${ }^{159}$ In Horowitz and Ewing, the Supreme Court decided the cases on the constitutional question of whether there was adequate process and not the state law question of whether the plaintiff had a property interest. ${ }^{160}$ If these applications were correct, it seems logical that all property interests should be treated in the same way. That would suggest courts should always determine whether there was enough process before determining whether a plaintiff has a property interest, which would be an illogical result. This use of the principle seems counter to the type of question the principle was designed to avoid, as the Supreme Court is actively trying to determine the constitutional question instead of the state law question.

Courts should not rely on constitutional avoidance as justification for not deciding the property interest question in education-based due process cases. The property interest question is both an essential element of a due process claim and a question of state law, meaning it is not an appropriate candidate for constitutional avoidance. The issue, though, is not the Supreme Court's use of the principle in the 1970s and 1980s; instead, it is the continued use today of the assumption approach by lower courts. It is unclear whether lower courts using the assumption approach do so because of constitutional avoidance. Some courts have specifically discussed and cited constitutional avoidance as the reason for their decisions to assume a property interest existed, ${ }^{161}$ while others have provided no justification for their decisions to assume that an interest existed. ${ }^{162}$ Either way, constitutional avoidance does not appear to be an adequate justification; therefore when courts face the property interest in education question, they should not rely on constitutional avoidance.

\footnotetext{
157. See supra Sections II.B-C.

158. Cleveland Bd. of Educ. v. Loudermill, 470 U.S. 532, 541 (1985) (holding that the Constitution, and not state law, defines the required amount of process due).

159. Id.

160. See Bd. of Curators of the Univ. of Mo. v. Horowitz, 435 U.S. 78, 84-85 (1978); Regents of the Univ. of Mich. v. Ewing, 474 U.S. 214, 222-23 (1985).

161. See, e.g., McMahon v. Salmond, 573 F. App'x 128, 133 (3d Cir. 2014) (citing Ewing, 474 U.S. at 222-25).

162. See, e.g., Richmond v. Fowlkes, 228 F.3d 854, 857 (8th Cir. 2000).
} 


\section{Guidance to Lower Courts}

The Supreme Court's decisions in Horowitz and Ewing did not create precedent on whether students have a property interest in their education, and therefore the Supreme Court failed to provide guidance to lower courts. In Horowitz and Ewing, the Supreme Court assumed that the plaintiffs had a property interest in their education instead of actually determining that the plaintiffs had such an interest. ${ }^{163}$ The Supreme Court did not actually create precedent on the question because it did not address the merits of the question. This lack of precedent has meant a lack of guidance for lower courts, which has caused uncertainty. ${ }^{164}$ This section will examine how this lack of guidance affects both lower federal courts and state courts.

\section{a. The Assumption Approach Creates Uncertainty for Lower Federal Courts}

Without guidance, lower courts have developed different approaches to handle student education claims. ${ }^{165}$ For example, some courts have moved away from the assumption approach and are now deciding whether students have a property interest. ${ }^{166}$ However, subsequent courts in the same circuit do not always follow their example and instead continue to assume that a property interest exists based upon Horowitz and Ewing. ${ }^{167}$ Intra-circuit splits create problems because they breed uncertainty. ${ }^{168}$ This uncertainty means that district courts in these circuits may be confused about what approach to use for determining property interests in education.

The First Circuit provides a good example of this problem. First, a First Circuit panel in Gorman v. University of Rhode Island held that "[i]t is . . . not questioned that a student's interest in pursuing an education is included within the fourteenth amendment's protection of

\footnotetext{
163. See Horowitz, 435 U.S. at 84-85; Ewing, 474 U.S. at 222-23.

164. See Mary D. Fan, Constitutionalizing Informational Privacy by Assumption, 14 U. PA. J. CONST. L. 953, 972-73 (2012) (examining an assumption approach in the context of a right to informational privacy).

165. See supra Section II.B-C.

166. See Vigil v. Regents of the Univ. of Mich., 980 F. Supp. 2d 790, 803 (E.D. Mich. 2013) (recognizing a split on how the Sixth Circuit has dealt with these types of interests), aff'd, $609 \mathrm{~F}$. App'x 349 (6th Cir. 2015).

167. See id.

168. Michael Duvall, Resolving Intra-Circuit Splits in the Federal Courts of Appeal, 3 FED. CTS. L. REV. 17, 17-19 (2009).
} 
liberty and property. Hence, a student facing expulsion or suspension from a public educational institution is entitled to the protections of due process." 169 Eleven years later, another First Circuit panel in Hennessy v. City of Melrose once again visited the question of a university student's property interest in her education. ${ }^{170}$ Instead of relying on Gorman and determining there was a property interest, the panel assumed such an interest existed "[i]n an abundance of caution." "171 Even more problematic, the panel in Hennessy was skeptical about whether an interest should exist all. ${ }^{172}$ While many district courts in the First Circuit have considered education due process cases since Gorman and Hennessy, not a single district court case has cited both Gorman and Hennessy even though both cases appear to be on point in the circuit. For example, in Gomes v. University of Maine System, a district court considered only Gorman and did not acknowledge the more recent Hennessy at all in determining whether a student had a property interest in her education. ${ }^{173}$ Thus, district courts must choose which circuit panel to follow, and therefore courts never establish precedent because courts can switch back and forth between the two approaches.

Another effect of the uncertainty from the assumption approach is that it taxes judicial resources. It does so in two ways. First, it creates inefficiency by not setting precedent on the property interest question. ${ }^{174}$ Precedent creates efficiency by removing the burden on decision makers to address each case as if it were a case of first impression. ${ }^{175}$ As one scholar noted about the importance of precedent:

When a precedent has no decisional significance as a precedent, the conscientious decisionmaker must look at each case in its own fullness. But when a rule external to the decisionmaker compels reliance on the decisions of others, it frees the decisionmaker from these responsibilities .... Thus, a decisionmaker choosing to rely on precedent may justifiably 'relax,' in the sense of engaging in less

169. Gorman v. Univ. of R.I., 837 F.2d 7, 12 (1st Cir. 1988) (citation omitted) (first citing Goss v. Lopez, 419 U.S. 565, 574-76 (1975); and then citing Dixon v. Ala. State Bd. of Educ., 294 F.2d 150, 157 (5th Cir. 1961)).

170. 194 F.3d 237, 249-50 (1st Cir. 1999).

171. Id. at 250 .

172. Id. at 249-50 (citing Regents of the Univ. of Mich. v. Ewing, 474 U.S. 214, 229 (Powell, J., concurring)).

173. 365 F. Supp. 2 d 6, 15-17 (D. Me. 2005).

174. In both Horowitz and Ewing, the Supreme Court chose to not create precedent on whether students have a property interest in their continued enrollement at a university or other institute of higher education. See Bd. of Curators of the Univ. of Mo. v. Horowitz, 435 U.S. 78, 84-85 (1978); Regents of the Univ. of Mich. v. Ewing, 474 U.S. 214, 222-23 (1985).

175. See Frederick Schauer, Precedent, 39 StAN. L. REV. 571, 599 (1987). 
scrutiny of the case, where that decisionmaker chooses to rely on a precedent. And where a rule of precedent urges a decisionmaker to relax in this sense, the net product will be a substantial reduction in decisionmaking effort. ${ }^{176}$

The assumption approach undermines this efficiency by requiring courts to continually re-evaluate whether a property interest exists. As previously mentioned, the First Circuit cases provide an example of the inefficiency of not having precedent on this topic. ${ }^{177}$ Instead of looking to binding precedent, courts have to constantly re-evaluate where a student has a property interest in her education. Second, it taxes judicial resources by forcing courts to hear claims that may be meritless. Courts do not want to interpret precedent incorrectly, so they assume property interests exist, even if they do not believe the interests exist. ${ }^{178}$ This means courts hear cases that may have no merit in the first place, but, because of the assumption approach, the courts must continue to entertain them, which is a waste of judicial resources. Ultimately, the assumption approach leaves it to the lower courts to handle the property interest question, but that can be taxing on judicial resources, as there is no clear path to go forward.

\section{b. The Assumption Approach Creates Uncertainty for State Courts}

The assumption approach has also affected state courts and altered the way they consider education-based due process claims. State courts may suffer from many of the same problems as other lower federal courts, but Horowitz and Ewing also affect them differently due to their connection with state law. Since Horowitz and Ewing, state courts have frequently assumed that a property interest existed in education-based due process claims. ${ }^{179}$ Courts normally follow the same pattern as Horowitz and Ewing. For example, the Texas Court of Appeals held that "[e]ven assuming that appellant had a protectible property right that gave rise to procedural rights under the due process clause, the facts in the

\footnotetext{
176. Id.

177. See supra notes $169-73$ and accompanying text.

178. See, e.g., Hennessy v. City of Melrose, 194 F.3d 237, 249-50 (1st Cir. 1999) (assuming a property interest exists in an "abundance of caution" even though the court found that a property interest was "dubious" (citing Ewing, 474 U.S. at 229 (Powell, J., concurring))).

179. See, e.g., Nickerson v. Univ. of Alaska Anchorage, 975 P.2d 46, 52 (Alaska 1999); Lachtman v. Regents of the Univ. of Cal., 70 Cal. Rptr. 3d 147, 156 (Cal. Ct. App. 2007); Lunde v. Iowa Bd. of Regents, 487 N.W.2d 357, 361 (Iowa Ct. App. 1992); Doe v. Bd. of Regents of the Univ. of Neb., 788 N.W.2d 264, 293 (Neb. 2010); Tobias v. Univ. of Tex. at Arlington, 824 S.W.2d 201, 209 (Tex. App. 1991).
} 
present case show that appellant was afforded adequate procedural due process." 180

State courts' using the assumption approach is problematic because that means state courts are not interpreting their own laws. The question of whether a person has a property interest is largely a question of state law. ${ }^{181}$ Therefore, state courts are actually the entities best fit to determine whether a student has a property interest. ${ }^{182}$ Yet, under the current approach, state courts follow the United States Supreme Court in assuming a property interest exists based upon their own laws but not actually deciding that question. Some courts, such as the Supreme Court of Hawaii, have rejected this approach and instead have examined their own laws to determine whether a student has an interest or not. ${ }^{183}$ Another issue with state courts' using the assumption approach is that state courts are no longer providing guidance to federal courts on what their laws mean. This is problematic because federal courts using the state-specific approach to education-based property interests rely upon state courts to determine whether a property interest exists. ${ }^{184}$ As state courts are the ultimate interpreters of their own statutes, it is logical that state courts should not rely on the assumption approach when addressing property interests in education.

\section{Actively Deciding the Property Interest Question Will Best Protect Defendants}

When courts use the assumption approach, they fail to address a large portion of a due process claim, and that means defendants may face claims that are lacking in merit. The assumption approach does not meet modern pleading standards because it allows plaintiffs to present a claim that is missing an essential element. Pleadings standards in the modern era have become stricter and require plaintiffs to show more than they might have in the past. ${ }^{185}$ In two cases, Ashcroft v. Iqbal ${ }^{186}$ and Bell Atlantic Corp. v. Twombly, ${ }^{187}$ the Supreme Court expanded the scope of

\footnotetext{
180. Tobias, 824 S.W.2d at 209.

181. See Bd. of Regents of State Colls. v. Roth, 408 U.S. 564, 577 (1972).

182. See Ikpeazu v. Univ. of Neb., 775 F.2d 250, 253 (8th Cir. 1985) (discussing the role of state law in determining whether a property interest in education existed).

183. See, e.g., Soong v. Univ. of Haw. at Hilo, 825 P.2d 1060, 1061-62 (Haw. 1992).

184. See Bd. of Curators of the Univ. of Mo. v. Horowitz, 435 U.S. 78, 87-88 (1978).

185. A. Benjamin Spencer, Plausibility Pleading, 49 B.C. L. REV. 431, 431-32 (2008)

186. 556 U.S. 662 (2009).

187. 550 U.S. 544 (2007).
} 
pleading requirements. ${ }^{188}$ The Supreme Court held that " $[\mathrm{t}]$ o survive a motion to dismiss, a complaint must contain sufficient factual matter, accepted as true, to 'state a claim to relief that is plausible on its face." "189 The Supreme Court went on to state: "A claim has facial plausibility when the plaintiff pleads factual content that allows the court to draw the reasonable inference that the defendant is liable for the misconduct alleged." 190 Therefore, in the modern pleading era, courts require plaintiffs to show they have a potentially valid claim, before a court will allow the claim to continue. ${ }^{191}$

Courts often use the assumption approach in a manner that is inconsistent with Iqbal/Twombly. Under the assumption approach, courts commonly allow claims to continue even if the plaintiff does not allege a property interest. ${ }^{192}$ As previously discussed, courts generally find that a preliminary question in any due process case is whether the plaintiff has a property interest (or another type of protected interest). ${ }^{193}$ Therefore, when a plaintiff does not allege a property interest, it does not appear to meet the plausibility standard as the claim is missing an essential element. ${ }^{194}$ In fact, many courts have found that the proper remedy if a plaintiff does not allege a protected interest is to dismiss the case under Federal Rule of Civil Procedure 12(b)(6). ${ }^{195}$ For example, in Bissessur v. Indiana University Board of Trustees, the Seventh Circuit held that "[the plaintiff's] complaint falls drastically short of providing the necessary factual details to meet the Twombly standard," because it failed to allege a property interest. ${ }^{196}$ As the assumption approach allows plaintiffs to continue their claim without alleging a property interest, it does not meet the heightened pleading requirements under Iqbal/Twombly. ${ }^{197}$

The assumption approach also imposes unnecessary costs upon defendants. The Iqbal/Twombly standards are designed to ensure that plaintiffs cannot "unlock the doors of discovery for a plaintiff armed

\footnotetext{
188. Arthur R. Miller, From Conley to Twombly to Iqbal: A Double Play on the Federal Rules of Civil Procedure, 60 DUKE L.J. 1, 9-10, 17-18 (2010).

189. Ashcroft, 556 U.S. at 678 (quoting Twombly, 550 U.S. at 570).

190. Id. (citing Twombly, 550 U.S. at 556).

191. Miller, supra note 188, at 19-21.

192. See, e.g., Bd. of Curators of the Univ. of Mo. v. Horowitz, 435 U.S. 78, 82 (1978); Trotter v. Regents of the Univ. of N.M., 219 F.3d 1179, 1184 (10th Cir. 2000).

193. See supra note 149 and accompanying text.

194. See Ashcroft, 556 U.S. at 678-79.

195. See Bissessur v. Ind. Univ. Bd. of Trs., 581 F.3d 599, 601-04 (7th Cir. 2009).

196. Id. at 603 .

197. See id. at 601-04.
} 
with nothing more than conclusions." "Twombly "teaches that a defendant should not be forced to undergo costly discovery unless the complaint contains enough detail, factual or argumentative, to indicate that the plaintiff has a substantial case." 199 In Bissessur, the Seventh Circuit noted that allowing a claim to continue without a valid property interest "would sanction a fishing expedition costing both parties, and the court, valuable time and resources." 200 Courts should not subject defendants to discovery under the assumption approach, as the approach does not meet the Iqbal/Twombly standards.

A prime example of this problem is Board of Curators of the University of Missouri v. Horowitz. ${ }^{201}$ As previously discussed, the plaintiff in Horowitz brought a due process claim against the University for her academic dismissal. ${ }^{202}$ In her complaint, Horowitz did not allege that she had a property interest in her education or provide a source of a property interest. ${ }^{203}$ Nevertheless, the district court allowed the claim to continue on the question of whether the University had provided Horowitz enough process. ${ }^{204}$ The case lasted over three years and made it on appeal all the way to the Supreme Court without ever resolving the property interest question. ${ }^{205}$ In contrast to the property interest question, the question the Supreme Court did consider - the adequacy of processinvolves factual considerations and discovery. ${ }^{206}$ Under Iqbal/Twombly, courts should instead dismiss cases that do not show a valid property interest to ensure that defendants are protected from discovery that should not occur.

\section{Actively Deciding the Property Interest Question Will Best Protect} Plaintiffs

The assumption approach is also harmful to plaintiffs, because courts allow claims to continue even if the claims are not viable. One of the reasons the assumption approach exists is that courts rarely find that

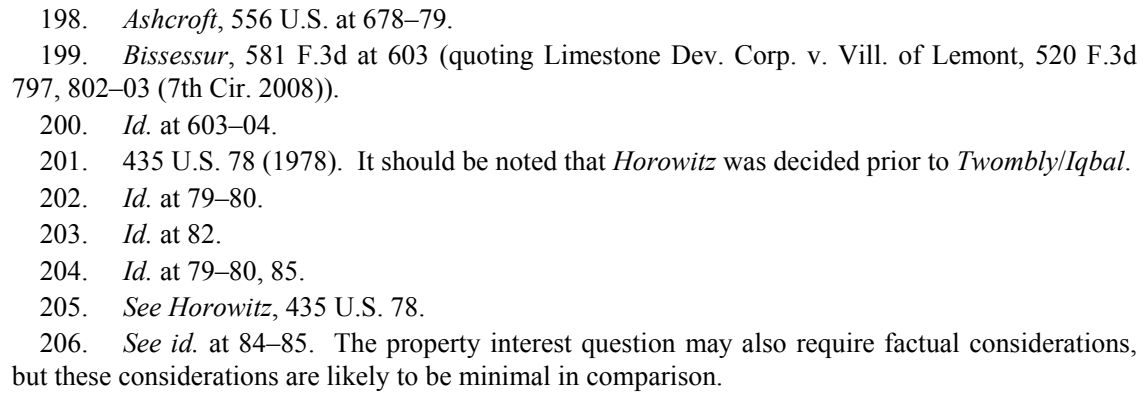


universities did not provide students enough process. ${ }^{207}$ Courts do not have to address the merits of the property interest question if they find that process was sufficient. ${ }^{208}$ This harms plaintiffs because it allows claims to continue even if they are not viable - meaning that plaintiffs can lose both time and money. Horowitz provides a good example of this, just as it does for defendants. ${ }^{209}$ The student in Horowitz had to spend three years to determine whether the University had provided her enough process, ${ }^{210}$ and if it had turned out she had not been provided adequate process, her case would have had to go back to the question of whether she had a property interest in the first place. This is an illogical and an unfair result for a plaintiff when the property interest question is a preliminary question.

The assumption approach also may represent a purposeful decision by the courts to avoid the property interest question. The Supreme Court, since the due process revolution, has been concerned about there being too many property interests protected by the Constitution. ${ }^{211}$ For example, some Supreme Court Justices worried in Goss v. Lopez that property interests were going too far. ${ }^{212}$ The Supreme Court has not altered, though, the parameters of property interests. ${ }^{213}$ Instead, courts have used "downstream" methods to "screen out such claims." "14 If the courts can find that a deprivation did not violate due process, then it is irrelevant whether the plaintiff has a property interest. ${ }^{215}$ Thus, students never know if they have a valid property interest. This constant cycle of indecision is unfair to both plaintiffs and defendants.

\section{B. Courts Should Use a State-Specific Approach for Determining Education Property Interests}

Courts should use state law to determine whether a student has a property interest in her education, instead of finding that there is a generalized property interest in education, for three main reasons. The

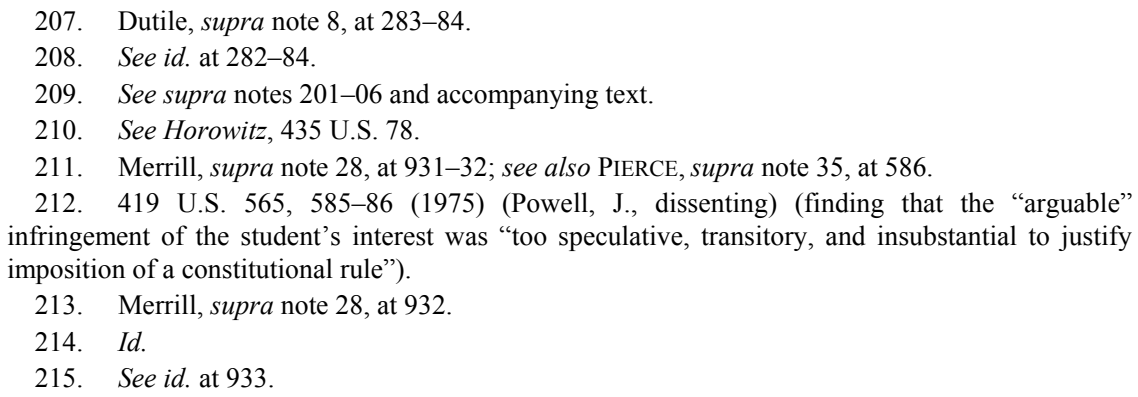


first is that Supreme Court precedent requires a state-specific approach because property interests must arise from independent sources of law. Second, courts need to switch to a state-specific approach because not all state laws provide students a property interest in their education. Third, the state-specific approach is practical to use and will still provide students procedural protections.

1. Issues with the Generalized Approach

Courts should choose to use the state-specific approach to property interests in education because it most closely follows precedent. It does so for three main reasons. First, Supreme Court precedent requires courts to look to state law and not the Constitution to determine property interests in education. ${ }^{216}$ The Supreme Court's detailed examination of state law in Goss v. Lopez supports this proposition. ${ }^{217}$ Second, courts should not use the generalized approach because it may dramatically expand the number of education-based property interests and removes the state's role in determining entitlements. Third, courts should avoid the generalized approach because it creates a constitutional circuit split.

\section{a. Supreme Court Precedent Requires a State-Specific Approach}

Supreme Court precedent requires that property interests come from an independent source of law such as state law. As previously discussed, the Supreme Court made it clear in Board of Regents v. Roth that the Constitution does not create property interests; instead, property interests derive primarily from state law. ${ }^{218}$ The Supreme Court has taken a hardline position on this and has ensured that state law provides the entitlements that property interests require. ${ }^{219}$ For example, in Leis $v$. Flynt, the Supreme Court rejected the plaintiffs' claim because the alleged property interest did not specifically arise from a state statute. ${ }^{220}$ The Supreme Court has been clear that unless a plaintiff can point to a specific state law, then she does not have a property interest.

The generalized approach conflicts with this precedent by allowing plaintiffs to have a property interest without considering state law. Circuits using the generalized approach normally rely upon Goss v.

\footnotetext{
216. Bd. of Regents of State Colls. v. Roth, 408 U.S. 564, 577 (1972).

217. See Goss, 419 U.S. at 573-74.

218. Roth, 408 U.S. at 577.

219. See Richard B. Stewart, Federalism and Rights, 19 GA. L. ReV. 917, 947 (1985).

220. 439 U.S. $438,441-43$ (1979).
} 
Lopez as the basis for the approach. ${ }^{221}$ In Goss, the Supreme Court held that a group of Ohio high school students had a property interest in their continued education. ${ }^{222}$ The Supreme Court found that Ohio state law provided the students a property interest because state law provided a free education to all primary students and mandated all students to attend primary school. $^{223}$ At no point did the Supreme Court recognize a generalized interest in education, which the Supreme Court's detailed analysis of Ohio state law demonstrates. ${ }^{224}$ The Supreme Court's later decisions in Horowitz and Ewing support the position that courts must look to state laws to find property interests in education. ${ }^{225}$ In Horowitz and Ewing, the Supreme Court assumed a property interest existed in education. $^{226}$ If the Supreme Court believed that Goss stood for the proposition that all students have a property interest in education, then the Court would have recognized such an interest in Horowitz and Ewing, but it did not. Goss cannot serve as a basis for a generalized approach because the Supreme Court's actions show that courts should look to state law to determine if students have a property interest in their education.

\section{b. The Generalized Approach Undermines Supreme Court Precedent}

The generalized approach undermines Supreme Court precedent by removing states from the property interest question. The Supreme Court created the independent-source system to ensure that federal courts would not have to define property interests. ${ }^{227}$ The Supreme Court's reasoning was two-fold. First, the Supreme Court felt that federal judges were ill-suited to create a list of property interests, and that property interests "would be more objective and constrained" if courts relied upon state law. ${ }^{228}$ Courts have also expressed concern that property interests may become outdated if left to the courts to decide. ${ }^{229}$ The second reason

221. See, e.g., Gorman v. Univ. of R.I., 837 F.2d 7, 12 (1st Cir. 1988) (citing Goss, 419 U.S. at 574-75); Gaspar v. Bruton, 513 F.2d 843, 850 (10th Cir. 1975) (citing Goss, 419 U.S. at 574).

222. Goss, 419 U.S. at $573-74$.

223. Id. (citing OHIO Rev. Code ANN. §§ 3313.48, 3313.64, 3321.04 (West 1972 \& Supp. 1973)).

224. See id. at $572-76$.

225. See Regents of the Univ. of Mich. v. Ewing, 474 U.S. 214 (1985); Bd. of Curators of the Univ. of Mo. v. Horowitz, 435 U.S. 78 (1978).

226. Ewing, 474 U.S. at 222-23; Horowitz, 435 U.S. at 82-85.

227. See Merrill, supra note 28, at 920-21.

228. Id.

229. Joel Hugenberger, Note, Redefining Property Under the Due Process Clause: Town of 
is that the Supreme Court designed Roth and its line of cases to protect states and ensure they play a role in defining property interests. ${ }^{230}$ Specifically, the Supreme Court wanted to give the states the power to decide when they wanted to provide entitlements. ${ }^{231}$ The generalized approach undermines both of these goals by allowing courts, not states, to define whether students have a property interest in their education.

Some scholars have raised criticisms of relying upon state law to determine property interests, but these criticisms do not justify the generalized approach. Authors Sidney Shapiro and Richard Levy have argued that once a state provides a benefit, they should be required to provide enforceable standards for that benefit. ${ }^{232}$ Other scholars have also criticized the entitlement system because it rests the power to determine property interests in the hands of state legislative branches. ${ }^{233}$ Scholars, though, are not advocating for a change in just education property interests; instead they are advocating for changing the entire system. ${ }^{234}$ Therefore, it would not be appropriate to change it in just the education context.

The difficulty with a generalized property interest is defining its scope. For example, does it extend beyond enrollment to areas such as grades or scholarship? Courts have criticized the idea of a generalized property interest because such a property interest could be extended to many different areas. ${ }^{235}$ For example, one court feared that a generalized property interest would mean due process would entitle students to a hearing if the students received a grade they did not like. ${ }^{236}$ While that may seem like an absurd result, an Eighth Circuit panel has suggested that a student may have a property interest in grading to the extent a professor could not grade her "capriciously.",237 It could be extended further. For example, could a student have a property interest in a school-funded scholarship or a property interest in playing on the

\footnotetext{
Castle Rock v. Gonzales and the Demise of the Positive Law Approach, 47 B.C. L. REv. 773, 807-08 (2006).

230. See Peter N. Simon, Liberty and Property in the Supreme Court: A Defense of Roth and Perry, 71 CAL. L. REV. 146, 146, 152-53 (1983).

231. Id. at 183 .

232. See Shapiro \& Levy, supra note 27 , at 108, 134, 152-53.

233. See PIERCE, supra note 35, at 596-97.

234. See, e.g., Shapiro \& Levy, supra note 27.

235. See, e.g., Williams v. Wendler, 530 F.3d 584, 589-90 (7th Cir. 2008) (rejecting a standalone property interest due to the possible interests it could entail).

236. Id.

237. See Ikpeazu v. Univ. of Neb., 775 F.2d 250, 253 (8th Cir. 1985) (assuming without deciding that a student likely has a property interest in their grades).
} 
football team $?^{238}$ Some students have even alleged that they have a property interest in their future professional sports careers. ${ }^{239}$ Increasing property interests also increase costs, as states have to pay to provide more procedure for students. ${ }^{240}$ Courts should not use the generalized approach because it undermines Supreme Court precedent that calls for states, and not judges, to determine what property interests are.

\section{c. Constitutional Circuit Splits}

The different approaches to educational property interests create a constitutional circuit split that courts should seek to resolve. Constitutional circuit splits raise many issues that regular circuit splits may not. ${ }^{241}$ Courts in general try to avoid this type of circuit split because of a belief that constitutional law in particular should be uniform in the United States to protect the legitimacy of the courts. ${ }^{242}$ Constitutional circuit splits also raise practical concerns, such as their effect on the doctrine of qualified immunity. ${ }^{243}$ Qualified immunity requires that the law be settled before liability is imposed on state officials. $^{244}$ Therefore, plaintiffs will face difficulty in bringing due process claims until the property interest question is settled. ${ }^{245}$ The Supreme Court has also expressed concern with this type of circuit split because it means that individuals in some circuits will have rights, which individuals in other circuits will not have. ${ }^{246}$

\section{Differences Between the Two Approaches}

While many students will have similar property interests under both the state-specific approach and the generalized approach, there are

\footnotetext{
238. See Dutile, supra note 8, at 255-57 (citing Conard v. Washington, 814 P.2d 1242, 1246 (Wash. Ct. App. 1991), and discussing property interests that courts have recognized in education). 239. See, e.g., Austin v. Univ. of Or., No. 6:15-cv-02257-MC, 2016 WL 4708540, at *4 (D. Or. Sept. 8, 2016).

240. PIERCE, supra note 35, at 632.

241. See Wayne A. Logan, Constitutional Cacophony: Federal Circuit Splits and the Fourth Amendment, 65 VAND. L. REV. 1137, 1171-85 (2012) (finding that courts generally avoid this type of circuit split).

242. Id. at 1171-74.

243. Id. at $1174,1177-79$.

244. See Krainski v. Nev. ex rel. Bd. of Regents of the Nev. Sys. of Higher Educ., 616 F.3d 963, 969-71 (9th Cir. 2010) (citing Saucier v. Katz, 533 U.S. 194, 202 (2001)).

245. See id.; see also Austin v. Univ. of Or., No. 6:15-cv-02257-MC, 2016 WL 4708540, at *4 5 (D. Or. Sept. 8, 2016).

246. See Obergefell v. Hodges, 135 S. Ct. 2584, 2606 (2015).
} 
practical differences between the approaches. Two key differences are clear initially. First, students will only have a property interest in their education if a state law provides them that interest. ${ }^{247}$ Second, students will be required to assert a property interest at the beginning of their claim, or their claim will face dismissal. ${ }^{248}$ Notably, the state-specific approach may not provide all higher education students a property interest in their education. ${ }^{249}$ Lower courts using the state-specific approach have in the past rejected property interests in education based upon state law. ${ }^{250}$ While this raises legal considerations that have been already discussed, ${ }^{251}$ this section will focus on how the approach will function differently in practice. Thus, in general, there are differences between the two approaches. Two specific areas need to be examined to understand the practical differences. The first is contract law, which some have suggested may provide a property interest to all students. ${ }^{252}$ The second is primary education, which may affect how courts view property interests in higher education.

\section{a. Contract Law}

Contract law is a major source of property interests for students, but like other sources, contracts require courts to analyze state law to determine whether there is a property interest. Courts have been clear that not "every state contract gives rise to such a protectible property interest." 253 Normally, the question revolves around whether the contract "confers a protected status or where the contract provides that the state

247. See Barnes v. Zaccari, 669 F.3d 1295, 1303-05 (11th Cir. 2012) (citing Logan v. Zimmerman Brush Co., 455 U.S. 422, 430 (1982)).

248. See, e.g., Brown v. Brienen, 722 F.2d 360, 363 (7th Cir. 1983); Littlefield v. City of Afton, 785 F.2d 596, 600 (8th Cir. 1986), abrogated by Lemke v. Cass County, 846 F.2d 469 (8th Cir. 1987); Am. Mfrs. Mut. Ins. Co. v. Sullivan, 526 U.S. 40, 59 (1999); Ezekwo v. N.Y.C. Health \& Hosps. Corp., 940 F.2d 775, 787 (2d Cir. 1991) (Timbers, J., concurring in part and dissenting in part).

249. See, e.g., Davis v. George Mason Univ., 395 F. Supp. 2d 331, 335-36 (E.D. Va. 2005) (finding that Virginia law does not provide a property interest to students in their continued enrollment), aff'd, 193 F. App'x 248 (4th Cir. 2006).

250. See, e.g., id.

251. See supra Section III.B.1.

252. See, e.g., Ikpeazu v. Univ. of Neb., 775 F.2d 250, 253 (8th Cir. 1985) (citing Perry v. Sindermann, 408 U.S. 593, 601-02 (1972)); Ross v. Pa. State Univ., 445 F. Supp. 147, 152-53 (M.D. Pa. 1978) (citing Bishop v. Wood, 426 U.S. 341, 344 (1976)).

253. Linan-Faye Constr. Co. v. Hous. Auth. of Camden, 49 F.3d 915, 931-32 (3d Cir. 1995) (citing Unger v. Nat'l Residents Matching Program, 928 F.2d 1392, 1397 (3d Cir. 1991)) (considering the issue broadly). 
can terminate the contract only for cause. ${ }^{, 254}$ In the education context, lower courts have found that not all student-university relationships create contracts that give rise to property interests. ${ }^{255}$ Specifically, lower courts have rejected contracts that are not clear or specific enough to provide a property interest. ${ }^{256}$ While contract law may provide many students a property interest in their education, unlike the generalized approach, not all students will have a protected property interest.

\section{b. Primary Education}

While this Comment has focused on university-level education, the way in which the Supreme Court has handled primary education may help explain the generalized approach. As previously mentioned, in Goss, the Supreme Court held that the Ohio high school students had a property interest in their education based upon state laws that provided free education to all primary students and made it compulsory to attend. ${ }^{257}$ Based upon that holding, lower courts have generally held that primary students have a property interest in their continued enrollment in school. ${ }^{258}$ The reason for this is that since all states provide free primary education and compulsory education, ${ }^{259}$ then all primary students also have this property interest in their education. First, it should be noted that while primary students may have a property interest based upon Goss, that does not appear to be the case for university students because university-level education is not free or compulsory. Second, the relationship between a university student and a university is significantly different from the relationship between a primary student and a school. ${ }^{260}$ Third, the language of Goss and how courts have applied it to primary education may have influenced lower courts to believe it created a generalized property interest. ${ }^{261}$ While primary students may have a

254. KoCH, supra note 23, at 91.

255. See, e.g., Leone v. Whitford, No. 3-05-cv-823 (JCH), 2007 WL 1191347, at *8-9 (D. Conn. Apr. 19, 2007) (finding that the contractual relationship between the student and the university did not arise to the level of a property interest), aff'd, 300 F. App'x 99 (2d Cir. 2008).

256. See, e.g., Bissessur v. Ind. Univ. Bd. of Trs., 581 F.3d 599, 601-04 (7th Cir. 2009).

257. Goss v. Lopez, 419 U.S. 565, 573-74 (1975) (citing OHIO REv. Code ANN. §§ 3313.48, 3313.64, 3321.04 (West 1972 \& Supp. 1973)).

258. See Larry Bartlett \& James McCullagh, Exclusion from the Educational Process in the Public Schools: What Process is Now Due, 1993 BYU EDUC. \& L.J. 1, 52-53.

259. Chelsea Lauren Chicosky, Restructuring the Modern Education System in the United States: A Look at the Value of Compulsory Education Laws, 2015 BYU EDUC. \& L.J. 1, 21.

260. Dutile, supra note 8, at 253.

261. See, e.g., Gorman v. Univ. of R.I., 837 F.2d 7, 12 (1st Cir. 1988); Gaspar v. Bruton, 513 F.2d 843, 850 (10th Cir. 1975). 
property interest that is close to universal, this line of reasoning does not apply to higher education, and therefore a state-specific approach will not provide the same interests as a generalized approach.

\section{Advantages of the State-Specific Approach}

A state-specific approach has both practical and legal advantages. Many of the legal benefits have already been mentioned such as closely following Supreme Court precedent, ensuring courts do not have to determine what is a property interest, and preventing a constitutional circuit split. ${ }^{262}$ In addition to these legal advantages, a state-specific approach also provides other advantages, including that it is practical to use and that it will not reduce protections for students. The next two sections will consider each of these advantages separately.

\section{a. The State-Specific Approach is Practical to Use}

The state-specific approach is efficient and easy for courts to manage. It should be noted that the generalized approach has inherent benefits as courts do not have to decide if a student has a property interest. However, the state-specific approach is also practical. There are many different methods that courts can rely on to determine whether a student has a property interest in her education. First, under the statespecific approach, it is the plaintiff's burden to prove she has a property interest in education. ${ }^{263}$ This means that courts will not have to struggle with finding property interests for plaintiffs as they will have to do so themselves. Notably, that also provides the benefit of ensuring that defendants are placed on notice of what interest the plaintiff is claiming. ${ }^{264}$ Federal courts also can rely on state courts to provide guidance on what state laws provide property interests. ${ }^{265}$ Finally, once a court determines that state law provides a property interest for a student, then another student in that state can use that decision as precedent, and so this area of law will be relatively stable, and courts can settle the law

262. See supra Section III.B.1.

263. See Bissessur v. Ind. Univ. Bd. of Trs., 581 F.3d 599, 601, 603-04 (7th Cir. 2009) (demonstrating that plaintiffs must state a plausible, valid entitlement in their complaint or the complaint will be dismissed).

264. See id.

265. See August v. L.A. Cmty. Coll. Dist. Bd. of Trs., No. 87-5559, 1988 WL 58001, at*3 n.2 (9th Cir. 1988) (analyzing California state court cases on property interests in education); Ikpeazu v. Univ. of Neb., 775 F.2d 250, 253 (8th Cir. 1985) (analyzing Nebraska state court cases on property interests in education). 
state-by-state over time. ${ }^{266}$ While a state-specific approach does require courts to evaluate state law to find a property interest, the approach is still efficient as courts have many tools available to them to determine if a student has a property interest in her education.

b. The State-Specific Approach Will Not Reduce Protections for Students

A state-specific approach will not guarantee every student a property interest in education, but it will still provide significant due process protections for students. If courts stop using the generalized approach, property interests will still exist under state law. ${ }^{267}$ In fact, many courts have found that state law provides students' property interests. ${ }^{268}$ While protections may not extend to more obscure interests, such as interests in grades, it will likely extend to core property interests such as continued enrollment in school. ${ }^{269}$ Therefore, many students will likely still have a property interest in their education under a state-specific approach.

Even if a student does not have a property interest, she is likely not lacking in process, because courts almost never find that a university did not provide a student enough process in "academic" (as opposed to "disciplinary") situations. ${ }^{270}$ Courts have held educational institutions to a very low bar on how much process they have to provide to students in these cases. ${ }^{271}$ Following the Supreme Court's lead in cases like Horowitz, courts largely defer to educational institutions and have avoided "second-guessing" their decisions in "academic" contexts. ${ }^{272}$ For example, one review of education-based due process claims found that of fifty-nine cases studied, in only five did the court find that process was not sufficient. ${ }^{273}$ While some students will not have a property interest in their education, that does not mean they will be losing process that they would otherwise get.

Finally, protections provided by universities are not necessarily tied to due process, and therefore many universities will continue to provide

\footnotetext{
266. See, e.g., Borrell v. Bloomsburg Univ., 955 F. Supp. 2d 390, 402-03 (M.D. Pa. 2013).

267. See supra Section II.B.1 (detailing how the state-specific approach can be used to find property interests in state law).

268. Dutile, supra note 8, at 254-57.

269. See supra Section II.B.1.

270. Dutile, supra note 8, at 289-90.

271. Id. at $282-88$.

272. Id. at 251

273. Ford \& Strope, supra note 17 , at 542 . It is important to note that the article's authors limited their study to "academic decisions," not "[d]isciplinary cases." Id. at 517, 517 n.3.
} 
protections for students whether a student has a property interest or not. The Due Process Clause only sets a threshold for what process is required, and universities can provide more protection than is required. ${ }^{274}$ And they do. A study of university protections showed that "most institutions afford their students procedural safeguards that current law does not require."275 Students can also look to other methods to protect their rights such as contract law, which can provide many similar protections to due process law. ${ }^{276}$ Under the state-specific approach, many universities will likely still provide protections for students regardless of whether the student has a property interest in her education.

\section{CONCLUSION}

When deciding due process claims brought by students, courts should no longer assume a property interest in education exists and instead should look to state law to determine whether a student has such an interest. Courts should actively decide the property interest question because it will provide guidance to lower courts and ensure judicial efficiency by creating precedent on the property interest question. This guidance will also help protect plaintiffs and defendants by ensuring that courts dismiss meritless claims and that resources and time are not wasted.

Courts should use the state-specific approach, instead of the generalized approach when determining whether a student has a property interest in her education. Supreme Court precedent has always required that property interests arise from state law, and therefore education property interests should follow this precedent. Furthermore, the two approaches have created a constitutional circuit split on the property interest question. Consequently, students in some circuits have a generalized property interest in education, while students in other circuits have to prove that state law provides them with such an interest. The state-specific approach will resolve these concerns while still being practical for the courts to use and not reducing protections for students.

Courts can and should change to a single-approach to property interests. Courts should no longer avoid the property interest question

274. See Dutile, supra note 8, at 280-82.

275. Curtis J. Berger \& Vivian Berger, Academic Discipline: A Guide to Fair Process for the University Student, 99 CoLuM. L. REv. 289, 297 (1999).

276. K.B. Melear, The Contractual Relationship Between Student and Institution: Disciplinary, Academic, and Consumer Contexts, 30 J.C. \& U.L. 175, 175-76 (2003) (discussing the role of contract law in the protections of both private and public students). 
but instead attempt to settle the question for students and educational institutions. Forty years after Goss, it is time for a single approach to education-based property interests to arrive. 